\title{
Sir Joseph Barcroft of Cambridge (1872-1947) and prenatal research
}

\author{
Peter M Dunn
}

Joseph Barcroft was born at the Glen, Newry, County Down on 26 July 1872, the second of five children. ${ }^{1-3}$ His parents, Henry and Anna, were Quakers, originally from Lancashire. His father worked in textiles (linen) and became deputy lieutenant of County Down and high sheriff of County Armagh. Joseph went to school at Bootham, the Friend's School at York, and then the Leys School, Cambridge. While still a schoolboy he was awarded a BSc (London, 1891).

After considering both the law and medicine, he opted for a career in physiology. Entering King's College Cambridge as an exhibitioner in 1894, he obtained first class honours in natural sciences (BA, 1896), was made a fellow of Kings (1899), won the Walshingham Medal for biological research (1899), and in 1900 shared the Gedge Prize for physiological research with $\mathrm{H}$ H Dale. That same year he was appointed to a lectureship in natural science at Kings, a post he held for 25 years. By the outbreak of the Great War he had already achieved international recognition for his work on the respiratory function of blood; a monograph with that title published in 1914 is still regarded as a classic. He also invented the Barcroft differential blood gas manometer and led two high altitude expeditions to Teneriffe (1910) and Monte Rosa (1911). In 1910 he was elected a fellow of the Royal Society. ${ }^{1-3}$

During the Great War he worked as civilian chief physiologist at the government's chemical warfare station, Porton near Salisbury. He occasionally used himself as a guinea pig. In 1918 he was awarded the CBE for his services.

Barcroft returned to Cambridge in 1919 as reader in physiology, working on the circulation, the distribution of blood, its storage and release by organs such as the spleen, and on the various causes of anoxaemia. In 1922 he led an Anglo-American expedition to the Peruvian Andes. Mount Barcroft in California was named after him. This period of his life culminated in the publication of another classic text on the architecture of physiological function (1934). Meanwhile many honours came his way: president of the physiological section of the British Association (1920), medal of the Royal Society (1922), the Fullerton Professorship of the Royal Institution (1922), the chair of physiology at Cambridge (1925) and honorary doctorates from six universities in Europe

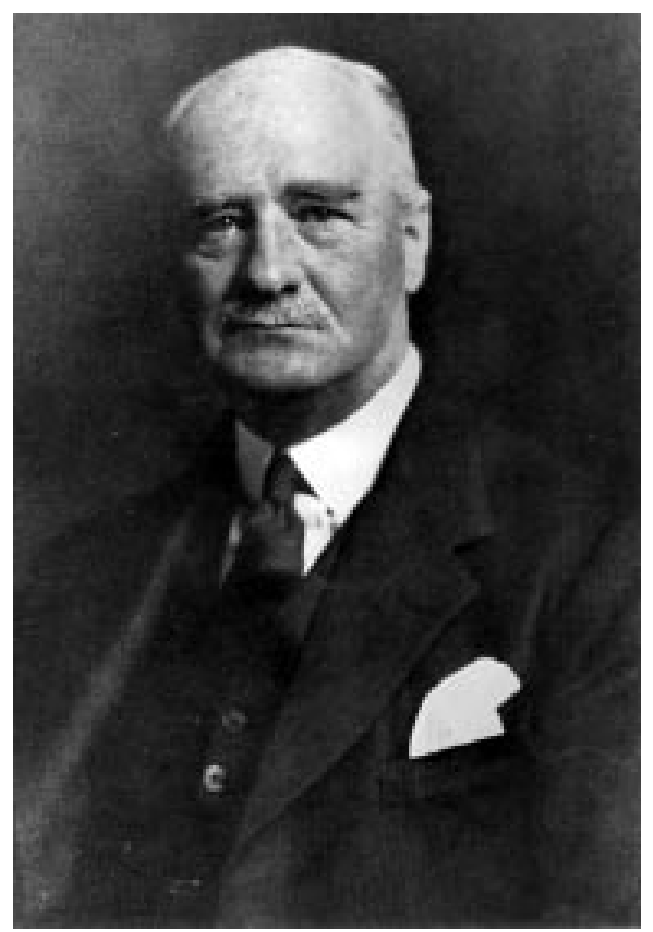

Figure 1 Sir Foseph Barcroft, 1872-1947.

and North America. In 1935 he received a knighthood (fig 1).

In 1932, when aged 60, Barcroft had begun the third and perhaps most important chapter of his scientific research-namely, study of the physiology of the developing fetus. Although interrupted briefly by a return during the war to Porton Down in 1939-41, he pursued this work right up to his sudden death 15 years later. He gave the Croonian Lecture of the Royal Society on fetal respiration (1935) and the Linacre Lecture at Cambridge on respiratory patterns at birth (1941). In 1937 he was made chairman of the Food Investigation Board and during the War was chairman of the Nutrition Society. In 1941 he returned to Cambridge as head of the newly formed animal physiology unit of the Agricultural Research Council, and contributed to important research on the physiology of digestion and metabolism. In 1944 the Royal College of Obstetricians and Gynaecologists made him an honorary fellow. Awarded the Copley Medal of the Royal Society in 1943, he was also made honorary fellow of the Royal Society (Edin) in 1944. A few weeks before his death from a 
heart attack on 21 March 1947, he published his third classic treatise: Researches in Prenatal Life. Part $I{ }^{4}$ It was dedicated to his brilliant colleague, Donald Barron.

In the 1920s A St G Huggett had introduced the technique of delivering fetal lambs by caesarean section into a saline bath at $37^{\circ} \mathrm{C}$ and Barcroft "applied this technique to the measurement of fetal blood volume and placental blood flow, the circulation through the chest and the fetal heart, the passage of oxygen and carbon dioxide across the placental membrane, the differences between maternal and fetal haemoglobin at various stages, the nervous control of respiration and of growth rate of the fetus and a host of other cognate problems." Barcroft himself wrote: "The aim then of this book is to trace the development of function in the mammalian foetus, never losing sight of the fact that one day the call will come and the foetus will be born. Not only has the foetus to develop a fundamental life which will suffice for intrauterine conditions, but at the same time it has to develop an economy which will understand the shock of birth, and will suffice, nay more than suffice, for its new environment."

Barcroft was not only a magnet for, and inspiration to, students from all over the world, but his studies and interest in perinatal physiology sparked a wide interest in this previously neglected field. Many distinguished scientists such as Robert McCance, Elsie Widdowson, Geoffrey Dawes, Kenneth Cross and many others in the USA followed in his footsteps. For example, Barclay, Franklin and Prichard, in the dedication of their book ${ }^{5}$ wrote: "The foetal studies at the Nuffield Institute were initiated in 1937 when Sir Joseph Barcroft and Dr DH Barron asked if we would co-operate, with our cineradiographic techniques, in the solution of their problem, namely, the determination of the time of functional closure of the ductus arteriosus."

This scientific initiative renewed clinical interest in fetal and neonatal medicine. Perinatal medicine had been given a scientific foundation.

Sir Joseph was a creative problem solver and was the leading experimental biologist for nearly half a century. As Barron wrote, his experiments were carefully planned with an objective easy to obtain and a broader remote goal. ${ }^{2} \mathrm{He}$ was an outstanding teacher, speaking without notes. His expositions were clear and simple and often laced with flashes of wit. $\mathrm{He}$ had a great capacity for work, combined with patience, tenacity, courage, sound judgment, enthusiasm, vision, freshness of mind and a sense of wonder at any problem under study. At the same time he was modest and generous with his credit to coworkers. He inspired affection in students and colleagues, always finding time to get to know his juniors and to offer help and advice when needed. A genial man, he was thoughtful and sympathetic. He had a great sense of humour, a genius for friendship, and loved good company. Barron ended his own tribute to him with the words: "None knew thee but to love thee, nor named thee but to praise."

In 1903 Barcroft had married Minnie Ball, the daughter of the famous astronomer, Sir Robert Ball. They made their home in Cambridge and were great hosts. Barcroft was a firm believer in the importance and sanctity of marriage, family life, and home, subjects which he took very seriously. Of their two sons, Henry became a physiologist, while Robert entered the army. Although he lived for his work, Barcroft had other hobbies which included reading, painting, riding, sailing and golf. Probably his greatest joy in life, though, was the knowledge of the affection and respect in which he was held, and the fact that his work would contribute to the better care of mothers and their children.

1 Roughton FJW. Joseph Barcroft 1872-1947. Royal Society of Obstetrics Notices 1948;6: 315-45.

2 Barron DH. Sir Joseph Barcroft. In: Foetal and Neonatal Physiology. Proceedings of the Sir Foseph Barcroft Centenary Symposium, Cambridge, fuly 1972. Cambridge: Cambridge University Press, 1973: xiv-xxiv.

3 Young M. Classics revisited: Researches on prenatal life by Sir Joseph Barcroft. Placenta 1992;13;607-12.

4 Barcroft Sir J. Research on prenatal life. Part I. Oxford: Blackwell Scientific Publications, 1947.

5 Barclay AE, Franklin KJ, Prichard MML. The foetal circulation. Oxford: Blackwell Scientific Publications, 1944 